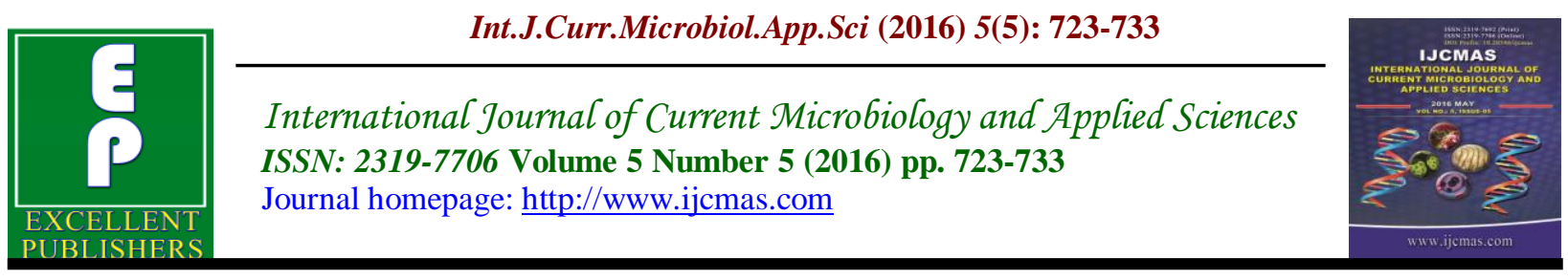

Original Research Article

http://dx.doi.org/10.20546/ijcmas.2016.505.073

\title{
Relative Salt Tolerance of Different Grape Rootstocks to NaCl
}

\author{
K. Saritha*, D. Vijaya, B. Srinivas Rao and M. Padma \\ Grape Research Station, Rajendranagar, Hyderabad \\ Sri Konda Laxman Telangana State Horticultural University, India \\ *Corresponding author
}

\section{Keywords \\ Salt tolerance, root to shoot ratio, $\mathrm{K} / \mathrm{Na}$ ratio, scorching injury.}

\section{Article Info}

Accepted:

18 April 2016 Available Online: 10 May 2016

\section{A B S T R A C T}

An experiment was conducted at Grape Research Station, Rajendranagar, Hyderabad to study the relative salt tolerance of grape rootstocks at different levels of sodium chloride. The treatments consisted of five rootstocks viz., Dogridge, Salt Creek, RS-19, SO4 and 1613-C and five levels of sodium chloride 4, 8, 16 and 32 meq of $\mathrm{Cl} / \mathrm{lt}$ in irrigation water including control (normal irrigation water ). The experiment was laid out in a FCRBD with three replications. The relative salt tolerance was judged based on growth parameters, dry weight of root to shoot ratio, symptoms of toxicity, chloride content $\mathrm{K} / \mathrm{Na}$ ratio in leaf and days taken for appearance of toxicity symptoms. The dry weight of root to shoot ratio was significantly higher in Dogridge (0.6) and RS-19 when compared to others. The K/Na ratio in 1613-C (14.1) SO4 (13.4) and RS-19 (10.3) was significantly higher than Dogridge (8.8) and Salt Creek (7.4). Dogridge was the best chloride excluder based on lowest concentrations of accumulated $\mathrm{Cl}$ - in laminae $(0.8 \%$.). The scorching symptoms due to salt toxicity were observed earlier in RS 19 followed by Salt Creek, Dogridge, 1613 C and later in SO4. High innate vigour (high dry weight of root to shoot ratio and growth parameters) of Dogridge combined with high chloride exclusion ability represents the best combination for salt tolerance which however, could not be supported by low K/Na ratio. In case of $1613 \mathrm{C}$ and $\mathrm{SO} 4$, the high $\mathrm{K} / \mathrm{Na}$ ratio and late appearance of salt toxicity symptoms supported salt tolerance but less vigour and chloride exclusion were not in support relative to Dogridge. In all the rootstocks there was progressive decline in the growth parameters, $\mathrm{K} / \mathrm{Na}$ ratio, root to shoot ratio and increase in chloride content with the increase in concentration of $\mathrm{NaCl}$ over control. Such information further supported by field studies could assist in assessment of rootstocks for areas of high salinity.

\section{Introduction}

Grapevine is used for table, juice, wine and dried grape production, is an economically important fruit crop that is moderately sensitive to salinity. In Telangana State grape production has become the most coveted farming enterprise because of the suitable climate, soil and high returns. Dogridge (Vitis champini) is the most common rootstock used by grape growers for grafting Thompson Seedless, the popular commercial variety of this region. It is mainly grown in Rangareddy, Medak and 
Mahaboobnagar districts of Telangana State. Salinity is an increasing threat for horticulture and is a major factor in reducing plant productivity (Bohnert et al., 1995). In this region the chloride levels in irrigation water were reported to be more than the threshold limit of $4 \mathrm{meq} / 1$ in nearly $60 \%$ of the vineyards (GRS Annual report, 20082009). In grapevine salt stress symptoms include leaf burn, reduced vigour and reduced yield with a strong positive correlation between the two (Downton WJS, 1977). There is a strong influence of rootstock on scion production upon salt stress. Hence, the effect of excess salts can be avoided by using salt tolerant grape rootstocks. Rootstocks obtained from wild Vitis species differ widely in their capability to tolerate salinity. Downton and Hawker (1980) reported that root growth was more adversely affected than shoot growth under salinity environment studies therefore the ratio of root to shoot is more important in salt tolerance. Walker et al., 2002a concluded that a high innate vigour of a rootstock combined with moderate to high chloride and sodium exclusion ability represents the best combination for salt tolerance. Increased evidence shows that it is not the absolute quantity of $\mathrm{Na}+$ per se that influences salt resistance, but rather the cytosolic $\mathrm{K}+/ \mathrm{Na}+$ ratio that determines plant salt tolerance (Shabala and Pottosin, 2010). The very fact that there are marked differences of relative salt tolerance among the rootstocks emphasizes the importance of this study. Very limited information is available with respect to the response of rootstocks to salinity. Hence, the present study was aimed to screen grape rootstocks for their relative salt tolerance to $\mathrm{NaCl}$ salinity based on growth parameters, dry weight of root to shoot ratio, symptoms of toxicity, chloride content, $\mathrm{K} / \mathrm{Na}$ ratio in leaf and days taken for appearance of toxicity symptoms.

\section{Materials and Methods}

The present pot culture study was conducted at Grape Research Station, Andhra Pradesh Horticultural University, Rajendhranagar, Hyderabad during the year 2008-09. It is situated at an altitude of 530.38 meters above M S L and geographically lies at a latitude of $17020^{\prime} \mathrm{N}$ and longitude of $780.25^{\prime} \mathrm{E}$. The treatments consisted of 25 treatment combinations with an objective to screen five rootstocks viz., Dogridge (Vitis champini), Salt Creek (Vitis champini), RS19(Ramsey (V. candicans x V. rupestris) and Schwarzmann (V. riparia $\mathrm{x} V$. rupestris)), SO4 (Vitis berlandieri $x$ Vitis riparia) and 1613-C (Vitis solonis $\mathrm{x}$ Othello) against five levels of sodium chloride concentrations viz., control (normal irrigation water ), 4, 8, 16 and $32 \mathrm{meq} \mathrm{Cl/lt}$ in irrigation water. The experiment was laid out in a FCRB with three replications and three rootstocks in each replication. Six months old rooted cuttings of rootstocks were planted in earthen pots filled with soil collected from Grape Research Station, Rajendranagar and rotten FYM mixed well in $3: 1$ proportion. After the initial establishment, the rootstocks were irrigated with saline water prepared by mixing sodium chloride (control, 4, 8, 16 and 32 meq $\mathrm{Cl} / \mathrm{lt}$ ) in irrigation water for three months. The plants were irrigated with uniform volume of water below the field capacity. The irrigation water (control) was neutral ( $\mathrm{pH} 7.5)$, slightly saline $(0.85 \mathrm{dSm}-$ 1) with chloride (2 meq 1-1) and sodium (0.5 meq 1-1) levels below the threshold limit. It was safe with respect to residual sodium carbonate and sodium adsorption ratio. The soil used for pot filling was sandy clay loam in texture, low in organic carbon $(0.35 \%)$, low in available nitrogen (225 kg ha-1) and phosphorus $(9.5 \mathrm{~kg}$ ha-1), medium in potassium $(154 \mathrm{~kg} / \mathrm{ha})$. The soil was neutral in reaction $(\mathrm{pH}$ 7.1) and non saline (EC 
$0.32 \mathrm{dSm}-1)$. Standard procedures were followed for analysis of soil and water. Leaf toxicity (scorching) in grape rootstocks were recorded at different intervals. Based on the percentage of scorching the leaves were classified into $\mathrm{S} 1$ (initiation of scorching), $\mathrm{S} 2$ (<25\%), S3 (26 to $50 \%$ ), S4 (51 to 75 $\%)$ and S5 (> 75\%). Biometric observations per plant viz., number of roots $(\mathrm{cm})$, root volume $(\mathrm{cc})$, shoot length $(\mathrm{cm})$, number of leaves, dry weight of root (g) and dry weight shoot $(\mathrm{g})$ were recorded at the end of the experiment. The percent reduction in growth parameters at highest $\mathrm{NaCl}$ concentrations over control, dry weight of root to shoot ratio, $\mathrm{K} / \mathrm{Na}$ ratio was computed. The root volume was measured by water displacement method. The leaves were collected from each replication and were washed and oven dried at 700C temperature. Sodium content in leaves was determined using Flame photometer. Chlorides was determined by Argentometric titration (Richard, 1968)

\section{Results and Discussion}

Growth parameters Significant genotypic variation in growth parameters when exposed to added salt concentrations was evident from Table 1 and 2. Among the rootstocks the leaf number per plant was significantly highest in Dogridge which was on par with $1613 \mathrm{C}$ followed by SO4, RS19 and lowest in Salt Creek. This could be attributed to percent reduction over control.

However, highest shoot length was recorded in $\mathrm{SO} 4(80.3 \mathrm{~cm})$ while it was lowest in Dogridge $(60.2 \mathrm{~cm})$ and $1613-\mathrm{C}(61.3 \mathrm{~cm})$. In terms of percent reduction in shoot length maximum was recorded in Dogridge $(33.5 \%)$ and minimum in SO4 (18.1\%) (Table 4). The rootstocks did not vary significantly with respect to dry weight of shoots (Table 1).
Differences in root growth parameters of the rootstock were apparent with addition of $\mathrm{NaCl}$ salt. Of the rootstocks tested significantly highest root growth parameters reflected in terms of root number, volume and dry weight were recorded in Dogridge (55.2, 92cc and $21.2 \mathrm{~g}$ respectively) and lowest in Salt Creek $(42.7,82 \mathrm{cc}$ and $17.4 \mathrm{~g}$ respectively) in Table 2 . Percent reduction in root growth parameters of most rootstocks was in the following order RS 19> Dogridge $>$ SaltCreek > 1613 C > SO4 (Table 5). Similar reduction of dry matter weight under salt stress was previously reported by (Shani and Ben-Gal, 2005).

Thambe (1999) and Deshmukh et al., 2008 also recorded similar result with regard to these growth parameters in Dogridge when compared to 1616-C, Salt Creek and 1613-C rootstocks. The variation in growth parameters among various rootstocks might be due to high vigour, inherent genetic differences and their variations in adaptability to salinity environments (Shikhamany, 1999). According to Munns (2003), the decrease in plant biomass due to salinity may be related to low external water potential, ion toxicity, indirect effect on nutrients uptake and ion imbalance.

It was observed that in all the rootstocks there was a progressive decline in the growth parameters with the increase in the concentration of $\mathrm{NaCl}$ over control. However, the interaction effect of rootstocks and concentration was significant only for shoot length, average number of roots.). Sinel nikova et al., (1972) stated that increase in salinity levels caused decrease in plant hormone content (Auxin and Gibberellin) and increase in inhibitors level which restricted the growth and subsequent rooting. 
Dry weight of root to shoot ratio, $\mathrm{K} / \mathrm{Na}$ ratio and $\mathrm{Cl}$ content

The responses of rootstocks obtained from wild Vitis species to increasing concentrations of sodium chloride were examined in a pot culture experiment where changes in dry weight of root to shoot ratio, $\mathrm{K} / \mathrm{Na}$ ratio and $\mathrm{Cl}$ content could be related to salt tolerance (Table 3).

Of the rootstocks tested, higher dry weight of root to shoot ratio which is an indicator for salt tolerance was registered in Dogridge (0.6) and RS-19 (0.6) while in all other rootstocks an uniform ratio of 0.5 was recorded. Downton and Hawker (1980) reported that root growth was more adversely affected than shoot growth under salinity environment. Samra (1986) pointed out that root and shoot biomass production of grape was adversely affected as ESP increased.

Salinity tolerance was also associated with their ability to exclude $\mathrm{Na}+$ and/or $\mathrm{Cl}-$ or with $\mathrm{K} / \mathrm{Na}$ ratio. The $\mathrm{K} / \mathrm{Na}$ ratio has been considered to be a good indicator for salt stress (Devitt et al., 1981, Aslam et al., 1988). As per Levitt (1974) higher the K/Na in leaves more is the salt tolerance. There was significant variation in leaf $\mathrm{K} / \mathrm{Na}$ ratio a good indicator for salt stress.

Among the rootstock studied 1613-C maintained highest ratio (14.1) indicating salt tolerance and was statistically on par with SO4 (13.4) and RS-19 (10.3) while Salt Creek (7.4) recorded lowest ratio on par with Dogridge (8.8). Samra (1986) stated that tolerance seems to be related to $\mathrm{K} / \mathrm{Na}$ ratio in the leaf and not with absolute contents of sodium. The salt tolerant varieties maintained higher $\mathrm{K}$ levels than the sensitive ones (Troncoso' et al., 1999). The $\mathrm{K} / \mathrm{Na}$ ratio in leaf decreased significantly with increasing concentration of $\mathrm{NaCl}$. The least $\mathrm{K} / \mathrm{Na}$ in leaf was recorded with $32 \mathrm{meq}$ of $\mathrm{Cl} / \mathrm{lt}$ i.w. (5.13). The interaction between rootstocks $\mathrm{x}$ concentrations was found to be non significant with regards to $\mathrm{K} / \mathrm{Na}$ ratio in leaf.

High chloride exclusion ability also represents the salt tolerance (Walker et al., 2003) because salt-induced limitations in photosynthesis and stomatal conductance of grapevines are related to high $\mathrm{Cl}$ and not to $\mathrm{Na}$ contents in the leaves (Prior et al., 1992).

In the presence of salt, there was some variation among the rootstocks in the $\mathrm{Cl}$-concentrations. It is evident from the Table 3 that among the rootstocks Dogridge maintained lowest $\mathrm{Cl}$ - content $(0.88 \%)$ representing better salt tolerance than other rootstocks. Whereas, the other rootstocks under study did not show any significant difference among themselves. Significantly highest $\mathrm{Cl}$ - content in leaf $(1.78 \%)$ was recorded with 32 meq of $\mathrm{Cl} / \mathrm{lt}$ i.w. This was followed by progressive increase in $\mathrm{Cl}$ content in leaf with increase in concentration of Cl- salts. The lowest Cl- content in leaf was recorded with control $(0.51 \%)$. The interactions effect between rootstocks $\mathrm{x}$ concentrations was found to be non significant.

\section{Days Taken for Manifestation of Scorching Injury}

In results presented in the Table 6 revealed that the chloride toxicity symptoms on leaves were noticed earlier in RS-19 followed by Salt Creek and Dogridge rootstock where as manifestation of symptoms was late in 1613-C and SO4. Chloride accumulation causes burning on the leaf blades in high chloride treatment. (Ehlig, 1960 and Kupier, 1968). This could be because of high levels of chloride were observed in petiole and leaf lamina at abscission( Downton, 1977). 
Table.1 Effect of Varying Levels of Sodium Chloride Salt on Shoot Growth Parameters in Different Grape Rootstocks

\begin{tabular}{|c|c|c|c|c|c|c|c|c|c|c|c|c|c|c|c|c|c|c|}
\hline \multirow[t]{2}{*}{ Rootstocks } & \multicolumn{6}{|c|}{$\begin{array}{c}\text { Number of Leaves } \\
\text { Concentrations (meq of } \mathrm{Cl} / \mathrm{lt} \text { i.w.) }\end{array}$} & \multicolumn{6}{|c|}{$\begin{array}{c}\text { Shoot length(cm) } \\
\text { Concentrations (meq of Cl/lt i.w.) }\end{array}$} & \multicolumn{6}{|c|}{$\begin{array}{c}\text { Dry wt of } \operatorname{shoot}(\mathrm{g}) \\
\text { Concentrations (meq of Cl/lt i.w.) }\end{array}$} \\
\hline & Control & 4meq & 8meq & $\begin{array}{l}16 \\
\text { meq }\end{array}$ & $\begin{array}{l}32 \\
\text { meq }\end{array}$ & Mean & Control & 4meq & 8meq & $\begin{array}{l}16 \\
\text { meq }\end{array}$ & $\begin{array}{l}32 \\
\text { meq }\end{array}$ & Mean & Control & 4meq & 8meq & $\begin{array}{l}16 \\
\text { meq }\end{array}$ & $\begin{array}{l}32 \\
\text { meq }\end{array}$ & Mean \\
\hline Dogridge & 95.0 & 93.0 & 88.0 & 79.0 & 71.0 & 85.2 & 90.5 & 80.3 & 62.0 & 43.0 & 25.0 & 60.2 & 43.2 & 40.8 & 37.4 & 35.0 & 29.2 & 37.1 \\
\hline Salt Creek & 68.0 & 60.0 & 55.0 & 42.0 & 32.0 & 51.4 & 89.8 & 71.9 & 71.7 & 61.8 & 37.4 & 66.5 & 42.6 & 39.1 & 36.3 & 33.4 & 28.6 & 36.0 \\
\hline RS-19 & 80.0 & 76.0 & 69.0 & 58.0 & 45.0 & 65.6 & 96.1 & 72.7 & 64.0 & 59.7 & 50.3 & 68.6 & 42.0 & 39.6 & 37.7 & 34.4 & 29.9 & 36.7 \\
\hline SO4 & 90.0 & 86.0 & 74.0 & 63.0 & 54.0 & 73.4 & 98.0 & 85.9 & 78.0 & 74.3 & 65.1 & 80.3 & 42.8 & 40.6 & 35.8 & 33.4 & 30.3 & 36.6 \\
\hline 1613-C & 95.0 & 91.0 & 86.0 & 76.0 & 69.0 & 83.4 & 84.5 & 70.5 & 54.2 & 51.5 & 45.8 & 61.3 & 42.0 & 40.6 & 37.7 & 34.5 & 30.5 & 37.1 \\
\hline Mean & 85.6 & 81.2 & 74.4 & 63.6 & & & 91.8 & 76.3 & 66.0 & 58.1 & 44.7 & & 42.5 & 40.1 & 37.0 & 34.1 & 29.7 & \\
\hline $\begin{array}{l}\mathbf{R} \\
\mathbf{C} \\
\mathbf{R x C}\end{array}$ & & $\begin{array}{c}\text { SEm } \pm \\
\\
1.05 \\
1.05 \\
3.5\end{array}$ & $\begin{array}{c}\text { CD } \\
(\mathbf{0 . 0 5 p}) \\
3.2 \\
3.2 \\
\text { NS }\end{array}$ & & & & & $\begin{array}{c}\text { SEm } \pm \\
1.50 \\
1.50 \\
3.37\end{array}$ & $\begin{array}{c}\text { CD } \\
(\mathbf{0 . 0 5 p}) \\
4.6 \\
4.6 \\
10.3\end{array}$ & & & & & $\begin{array}{c}\text { SEm } \pm \\
\\
2.0 \\
1.27 \\
4.5\end{array}$ & $\begin{array}{c}\text { CD } \\
(\mathbf{0 . 0 5}) \\
\text { NS } \\
3.9 \\
\text { NS }\end{array}$ & & & \\
\hline
\end{tabular}


Table.2 Effect of Varying Levels of Sodium Chloride Salt on Root Growth Parameters in Different Grape Root

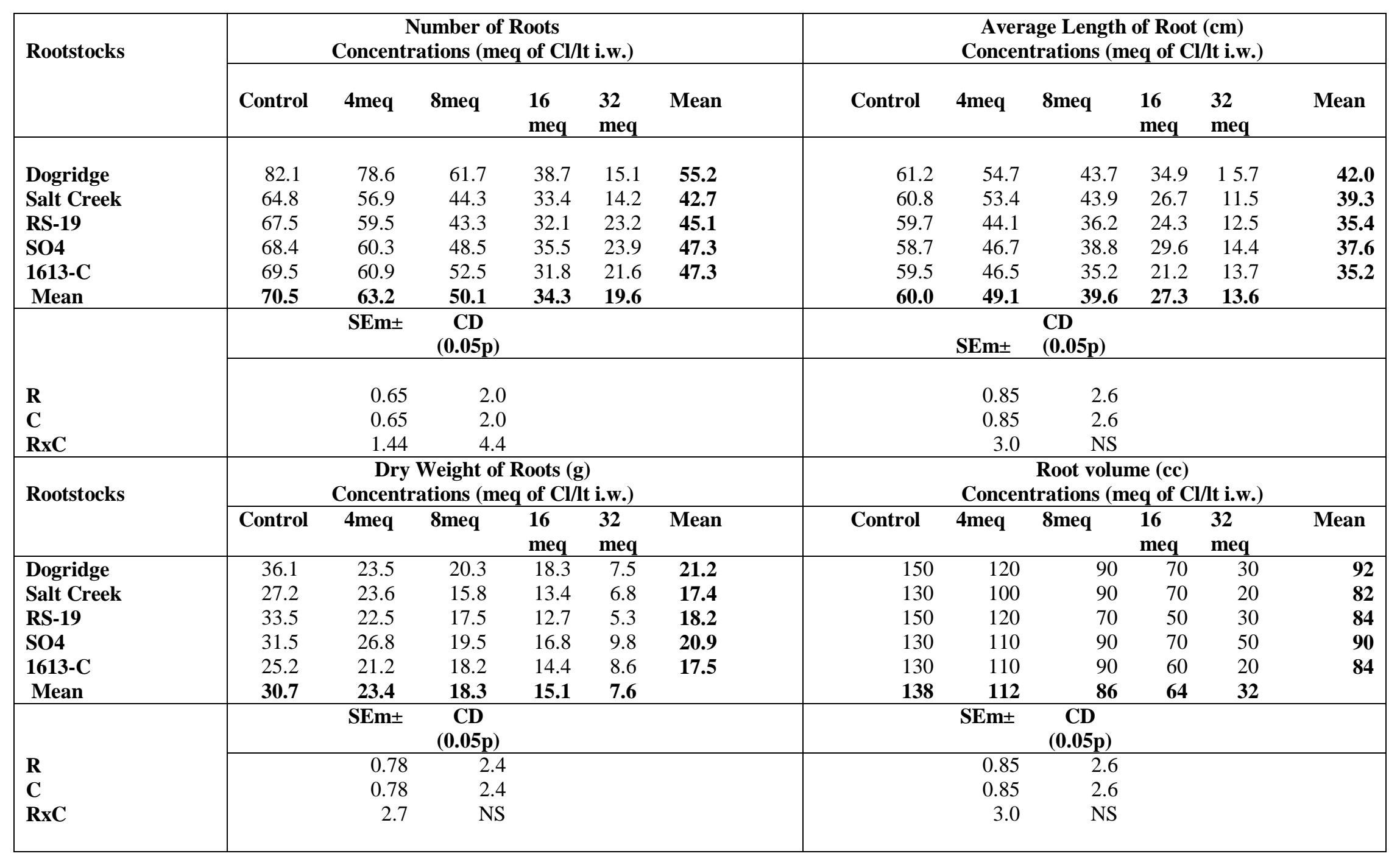


Table.3 Effect of Varying Levels of Sodium Chloride Salt on Root to Shoot Ratio, K/Na Ratio and Chloride Content in Different Grape Rootstocks

\begin{tabular}{|c|c|c|c|c|c|c|c|c|c|c|c|c|c|c|c|c|c|}
\hline \multirow{2}{*}{ Rootstocks } & \multicolumn{6}{|c|}{ Root to Shoot Ratio } & \multicolumn{5}{|c|}{$\mathrm{K} / \mathrm{Na}$ ratio } & \multicolumn{6}{|c|}{ Chloride content $(\%)$} \\
\hline & \multicolumn{6}{|c|}{ Concentrations (meq of $\mathrm{Cl} / \mathrm{lt}$ i.w.) } & \multicolumn{5}{|c|}{ Concentrations (meq of $\mathrm{Cl} / \mathrm{lt}$ i.w. } & \multicolumn{6}{|c|}{ Concentrations (meq of $\mathrm{Cl} / \mathrm{lt}$ i.w. } \\
\hline & Control & 4meq & 8meq & $\begin{array}{c}16 \\
\text { meq }\end{array}$ & $\begin{array}{c}32 \\
\text { meq }\end{array}$ & Mean & 4meq & 8 meq & $16 \mathrm{meq}$ & $\begin{array}{c}32 \\
\text { meq }\end{array}$ & $\begin{array}{c}\text { Mea } \\
\mathbf{n}\end{array}$ & Control & 4meq & 8 meq & $\begin{array}{c}16 \\
\text { meq }\end{array}$ & $\begin{array}{c}32 \\
\text { meq }\end{array}$ & Mean \\
\hline Dogridge & 0.83 & 0.58 & 0.55 & 0.51 & 0.25 & 0.60 & 14.21 & 8.87 & 7.06 & 4.92 & 8.76 & 0.47 & 0.67 & 0.85 & 1.1 & 1.28 & 0.88 \\
\hline Salt Creek & 0.63 & 0.60 & 0.43 & 0.39 & 0.23 & 0.50 & 12.77 & 7.65 & 5.32 & 3.79 & 7.38 & 0.64 & 0.89 & 1.2 & 1.38 & 2.41 & 1.31 \\
\hline RS-19 & 0.81 & 0.58 & 0.47 & 0.37 & 0.17 & 0.60 & 19.3 & 10.99 & 7.16 & 3.92 & 10.34 & 0.42 & 0.54 & 1.06 & 1.42 & 1.85 & 1.06 \\
\hline SO4 & 0.76 & 0.66 & 0.53 & 0.49 & 0.31 & 0.50 & 26.06 & 13.01 & 10.01 & 4.67 & 13.44 & 0.57 & 0.89 & 1.07 & 1.33 & 1.49 & 1.07 \\
\hline 1613-C & 0.60 & 0.51 & 0.49 & 0.41 & 0.26 & 0.50 & 20.03 & 17.56 & 10.22 & 8.37 & 14.05 & 0.46 & 0.78 & 0.92 & 1.14 & 1.88 & 1.04 \\
\hline Mean & 0.73 & 0.59 & 0.49 & 0.43 & 0.24 & & 18.5 & 11.62 & 7.95 & 5.13 & & 0.51 & 0.75 & 1.02 & 1.27 & 1.78 & \\
\hline & & $\begin{array}{c}\text { SEm } \\
\pm\end{array}$ & $\begin{array}{c}\text { CD } \\
(0.05 \\
\text { p) }\end{array}$ & & & & & $\mathbf{S E m} \pm$ & $\begin{array}{c}\text { CD } \\
(0.05 p)\end{array}$ & & & & SEm \pm & $\begin{array}{c}\text { CD } \\
(0.05 p)\end{array}$ & & & \\
\hline $\mathbf{R}$ & & 0.009 & 0.03 & & & & & 1.36 & 4.17 & & & & 0.03 & 0.1 & & & \\
\hline C & & 0.009 & 0.03 & & & & & 1.21 & 3.73 & & & & 0.03 & 0.1 & & & \\
\hline RxC & & 0.02 & 0.07 & & & & & 2.91 & N.S. & & & & 0.1 & NS & & & \\
\hline
\end{tabular}


Table.4 Percent Reduction in Growth Parameters of Different Grape Rootstocks due to Nacl

\begin{tabular}{|c|c|c|c|c|c|c|c|}
\hline \multicolumn{8}{|c|}{$\mathrm{NaCl}$} \\
\hline \multirow[b]{2}{*}{ leaf number per vine } & \multirow{2}{*}{$\begin{array}{r}\text { Salt Creek } \\
10 \\
\end{array}$} & \multirow{2}{*}{\begin{tabular}{c|}
\multicolumn{2}{c}{ RS-19 } \\
\end{tabular}} & \multirow{2}{*}{ SO4 } & \multicolumn{4}{|c|}{ MEAN } \\
\hline & & & & 18.0 & 18.4 & 12.2 & 16.6 \\
\hline Shoot length & 33.5 & & 25.9 & 28.7 & 18.1 & 27.6 & 26.8 \\
\hline Dry weight of shoot per vine & 14.1 & & 15.5 & 12.6 & 14.5 & 11.7 & 13.7 \\
\hline MEAN & 19.1 & & 21.95 & 19.78 & 17.0 & 17.15 & 19.0 \\
\hline
\end{tabular}

of Different Grape Rootstocks Due to Nacl

\begin{tabular}{|c|c|c|c|c|c|c|c|}
\hline \multicolumn{8}{|c|}{$\mathrm{NaCl}$} \\
\hline Dogridge & Salt Creek & RS-19 & 1613-C & \multicolumn{4}{|l|}{ MEAN } \\
\hline Number of roots per vine & & 32.8 & 34.1 & 33.2 & 30.8 & 31.9 & 32.6 \\
\hline Average length of roots per vine & & 31.2 & 35.4 & 40.9 & 35.9 & 40.8 & 36.8 \\
\hline Dry weight of roots per vine & & 40.2 & 36.0 & 45.7 & 33.4 & 30.6 & 37.2 \\
\hline Mean Reduction & & 35.73 & 35.60 & 40.95 & 32.73 & 34.68 & 35.93 \\
\hline
\end{tabular}


Table.6 Days for Manifestation of Injury Due to Varying Level of Nacl Salinity in Grape Rootstocks

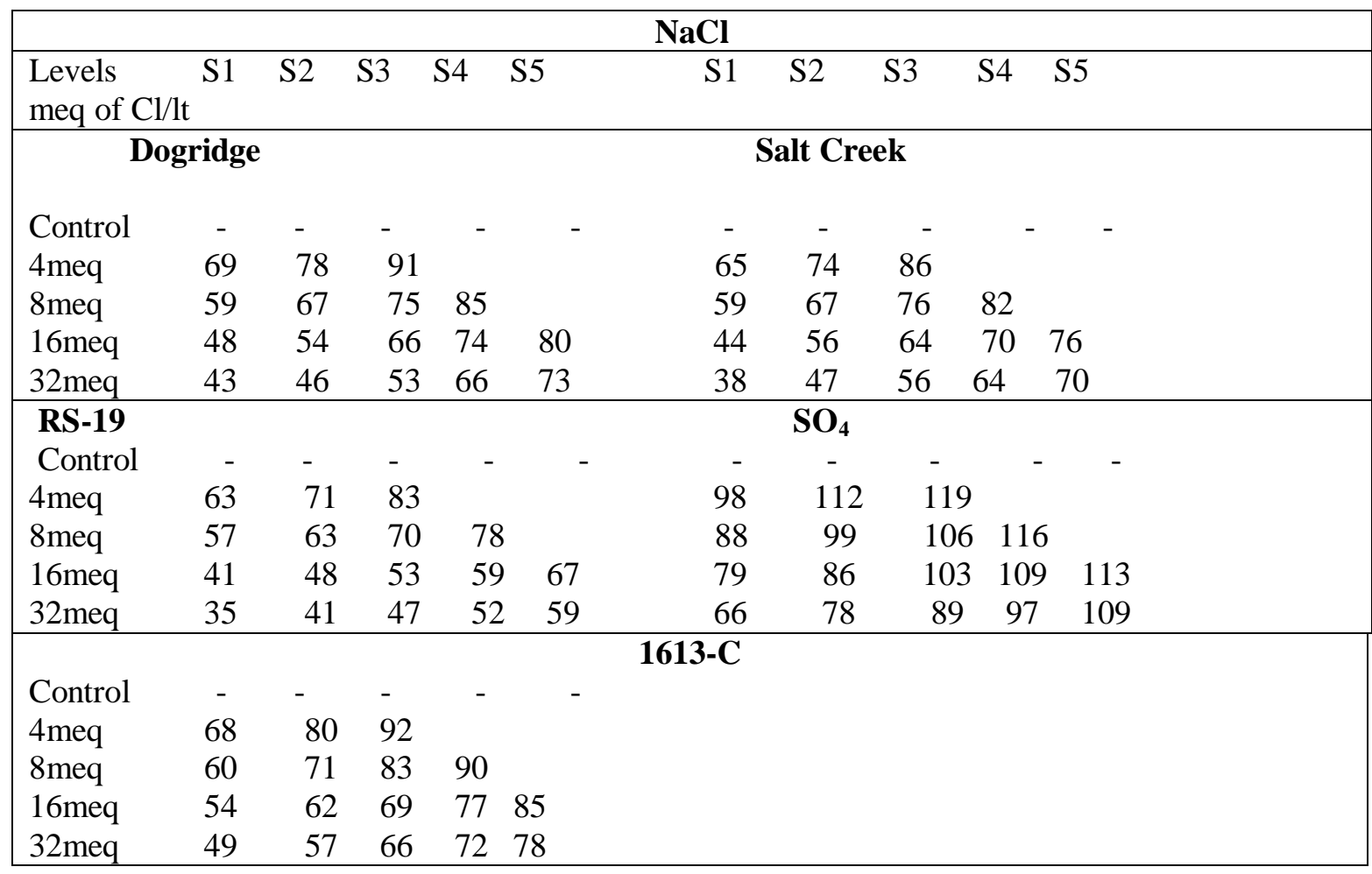

The highest rate of scorching S5 (> 75\% scorching), symptoms was observed at 32 and $16 \mathrm{meq}$ of $\mathrm{Cl} / \mathrm{lt}$ iw., concentration in all rootstocks,. Downton and Millhouse, 1983 reported that adding salt to the plants excessively causes salt injury and premature senescence in older leaves. Salt injury is more likely related to chloride, since $\mathrm{Cl}$ absorbs more quickly than sodium.

Putting together the combination of all the parameters for salt tolerance the high innate vigour (high dry weight of root to shoot ratio and growth parameters) of Dogridge combined with high chloride exclusion ability represents the best combination for salt tolerance which could not be supported by low $\mathrm{K} / \mathrm{Na}$ ratio. In all the rootstocks there was progressive decline in the growth parameters, $\mathrm{K} / \mathrm{Na}$ ratio, root to shoot ratio and increase in chloride content with the increase in concentration of $\mathrm{NaCl}$ over control. Such information further supported by field studies could assist in assessment of rootstocks for areas of high salinity.

In conclusion, the potential to provide a relative assessment of salt tolerance has been demonstrated in this study. High dry weight of root to shoot ratio, growth parameters combined with high chloride exclusion ability represented the best combination for salt tolerance in case Dogridge however, the $\mathrm{K} / \mathrm{Na}$ ratio was in less support of salt tolerance. In case of $1613 \mathrm{C}$, the high $\mathrm{K} / \mathrm{Na}$ ratio and late manifestation of salt toxicity symptoms supported salt tolerance however low root to shoot ratio and high chloride exclusion relative to Dogridge did not.

Therefore the potential of both Dogridge and $1613 \mathrm{C}$ for salt tolerance as concluded from 
this pot culture experiment when further supported by field studies could assist in assessment of rootstocks for areas of high salinity.

\section{References}

Alexander, D. McE., J., Groot-Obbink. 1971. Effect of chloride in solution culture on growth and chloride uptake of Sultana and Salt Creek grape vines. Aust. J. Exp. Agric. Animal Husb., 11: 357-361.

Aslam, M., Barret-Lennard, E.G., Greenway, H. 1988. Effects of external concentration of $\left(\mathrm{K}^{\prime}+\mathrm{Na}+\right)$ and $\mathrm{K}^{\prime} / \mathrm{Na}^{\prime}$ on the growth and ion relations of Atriplex amnicola. $J$. Plant Physiol., 133: 228-234.

Deshmukh, M.R., Karkamkar, S.P., Patil, S.G. 2008. Effect of Sodium Chloride on growth and chemical contents of grape rootstocks. Indian Jr. Hort., 65(3): 335-337.

Divate, M.R., Pandey, R.M. 1981. Salt tolerance in grapes II. Effect of salinity on mineral composition of plants. Indian J. Plant Physiol., 24(4):361-365.

Downton, W.J.S. 1977. Photosynthesis in salt-stressed grapevines. Aust. J. Plant. Physiol., 4: 183-192.

Downton, W.J.S. 1977a. Photosynthesis in salt stressed grapevines. Aust. J. Plant Physiol., 4: 183.

Downton, W.J.S. 1977b. Influence of rootstock on accumulation of chlorides, sodium and potassium in grapevines. Aust. J. Agric. Res., 28: 879-889.

Downton, W.J.S., Hawker, J.S. 1980. Interaction of boron and chloride on growth and mineral composition in relation of Cabernet Sauvignon vines. Am. J. Enol. Vitic., 31 (3): 277-282.
Ehlig, C.F. 1960. Effect of salinity of four varieties of table grapes grown in sand culture. Proc. Amer. Soc. Hort. Sci., 76: 323-331.

GRS, Annual Report, 2007-08. The nutrient survey around Hyderabad.

Kupier, P.J.C. 1968. Lipids in grape roots in relation to chloride transport. Plant Physiol., 43: 1367-1371.

Levitt, J. 1974. Response of plant to environmental stresses. N.Y. Acad. Press. New York. p.697.

Munns, R.. 2003. Physiological processes limiting plant growth in saline soils: some dogmas and hypotheses. Plant Cell Environ., 16: 15-24.

Prior, L.D., Grieve, A.M., Slavich, P.G., Culls, B.R. 1992. Sodium chloride and soil texture interactions in irrigated field-grown Sultana grapevines . 11 . Plant mineral content, growth and physiology. Aust. J. Agricult. Res., 43: 1067-1083.

Richadrs, L.A.(Ed.). 1968. Diagnosis and improvement of saline and alkaline soils. Agril. Handbook No.60: US. Dept of Agril. Washington.

Samra, J.S. 1986. Effect of soil sodicity on growth of four cultivars of grape. Indian J. Hort., 43(1\&2): 60-65.

Shabala, S., Pottosin, I.I. 2010. Potassium and potassium-permeable channels in plant salt tolerance. Signal. Commun. Plants, 87-110.

Shani, U., A.Ben-Gal. 2005. Long-term response of grapevines to salinity: Osmotic effects and ion toxicity. Am. J. Enol. Vitic., 56: 148-154.

Shikhamany, S.D. 1999. Sustaining the productivity of grape in saline-alkali soils. Souvenir, 3-9.

Sinel nikova, V.N., Romanova, L.V., Udovenko, G.V. 1972. Effect of salinization and physiologically active substances on growth and level of endogenous growth regulators in 
potato. Sov. Plant Physiol., 19(1): 5055.

Tambe, T.B. 1999. Ph.D (Agric). Rootstock studies in grapes (Vitis species). Thesis submitted to MPKV, Rahuri.

Troncoso, A., Villegas, A., Mazuelos, C., Cantos, M.1990. Growth and mineral composition of grape-vine rootstock cultured in vitro with different levels of amonium nitrate . In: VAN BEUSCHEN (Ed .) :Plant Nutrition, Physiology and Applications, 653654. Kluwer Academic Publishers, the Netherlands.

Walker, Deidre, H., Blackmore, Peter, R., Clingeleffer, Ray, L., Correll. 2004. Rootstock effects on salt tolerance of irrigated field-grown grapevines (Vitis vinifera L. cv. Sultana) 2. Ion concentrations in leaves and juice. Australian J. Grape and Wine Res., 90-99.

Walker, R.R., Blackmore, D.H., Clingeleffer, P.R., Correll, R.L. 2002. Rootstock effects on salt tolerance of irrigated field-grown grapevines ( Vitis vinifera L. cv. Sultana). 1. Yield and vigour inter-relationships. Aust. J. Grape Wine Res., 8(1): 3-14.

Walker, R.R., Blackmore, D.H., Clingeleffer, P.R., Godden, P., Francis, L. 2003. Salinity effects on vines and wines. Bulletin de l'O.I.V., 76: 200-227.

\section{How to cite this article:}

Saritha, K., D. Vijaya, B. Srinivas Rao and Padma, M. 2016. Relative Salt Tolerance of Different Grape Rootstocks to NaCl. Int.J.Curr.Microbiol.App.Sci. 5(5): 723-733. doi: http://dx.doi.org/10.20546/ijcmas.2016.505.073 